\title{
Grass Root-Knot Nematode Meloidogyne graminis Whitehead, 1968 (Nematode: Tylenchida: Meloidogynidae) ${ }^{1}$
}

\author{
William T. Crow ${ }^{2}$
}

\section{Introduction}

Root-knot nematodes (Meloidogyne spp.) are the most important plant-parasitic nematodes worldwide, with most temperate and tropical crops suffering yield losses from one or more species of Meloidogyne. Root-knot nematodes are the most widely recognized plant-parasitic nematodes because the characteristic galls or knots they cause on plant roots are easily observed symptoms for diagnosis. Meloidogyne graminis is damaging to many turf and forage grasses. Due to the prevalence of this nematode on grasses, and the prevalence of grasses compared to other crops in the state, it is likely the most widespread species of root-knot nematode in Florida. It is of increasing concern due to the rising importance of turfgrasses in the Florida economy, the susceptibility of grasses to this nematode, and implementation of new diagnostic techniques that have brought to light the damaging potential of this nematode.

\section{Importance}

The grass root-knot nematode is one of the three most important nematodes on golf course turf in Florida, together with sting nematode and lance nematode. It causes unsightly yellow blotches, thinning patches, and uneven playing surfaces on golf greens (Figure 1). On lawns and athletic fields it causes thinning patches, proliferation of weeds, and poor turf establishment (Figure 2). On sod farms it can cause compete yield loss by causing sod to fall apart during harvest. The amount of damage caused by Meloidogyne graminis to forage grasses is currently unknown, although studies to quantify this are in progress.

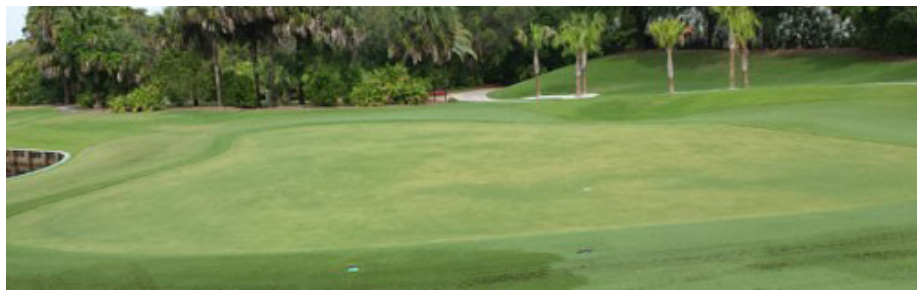

Figure 1. A bermudagrass golf course green infested by the grass rootknot nematode, Meloidogyne graminis Whitehead, showing chlorotic blotches.

Credits: William T. Crow, UF/IFAS

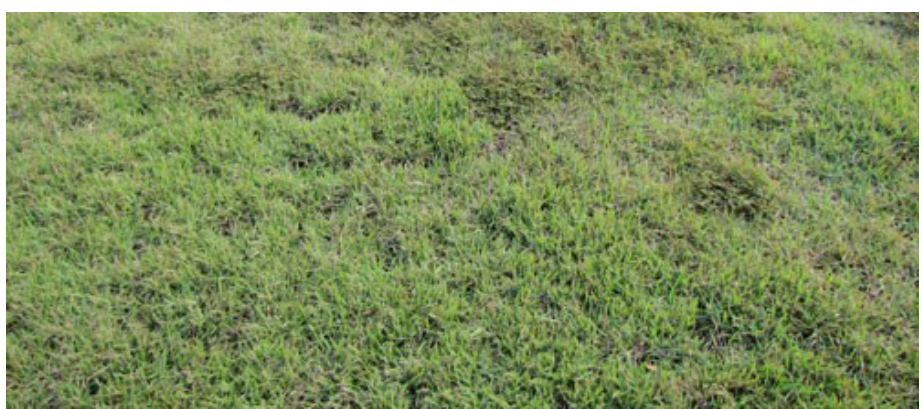

Figure 2. A zoysia lawn infested by the grass root-knot nematode, Meloidogyne graminis Whitehead, showing decline and weed proliferation.

Credits: William T. Crow, UF/IFAS

1. This document is EENY722, one of a series of the Department of Entomology and Nematology, UF/IFAS Extension. Original publication date January 2019. Visit the EDIS website at https://edis.ifas.ufl.edu for the currently supported version of this publication. This document is also available on the Featured Creatures website at http://entomology.ifas.ufl.edu/creatures.

2. William T. Crow, professor, Department of Entomology and Nematology; UF/IFAS Extension, Gainesville, FL 32611.

The Institute of Food and Agricultural Sciences (IFAS) is an Equal Opportunity Institution authorized to provide research, educational information and other services only to individuals and institutions that function with non-discrimination with respect to race, creed, color, religion, age, disability, sex, sexual orientation, marital status, national origin, political opinions or affiliations. For more information on obtaining other UF/IFAS Extension publications, contact your county's UF/IFAS Extension office. 


\section{Distribution}

Meloidogyne graminis is believed to be native to the United States. It was first described infecting St. Augustinegrass (Stenotaphrum secundatum) in Winter Haven, Florida, in 1964 (Sledge and Golden 1964) but has been reported on cultivated grasses from Florida to California and Hawaii (McClure et al. 2012), as far north as New England, and on native grasses in the Konza Prairie in Kansas. It is the most common root-knot nematode found on turf and forage grasses in Florida and golf course turf in the Carolinas (Zeng et al. 2012). Outside of the United States it has been reported in Europe from Sylt Island in Germany (Sturhan 1976) and the Netherlands (Wesemael et al. 2011), in South America from Venezuela (Perichi 2006) and Brazil (Oliveira et al. 2018), and in Asia from China (Zhuo et al. 2011). This nematode is a common endoparasite of bermudagrass (Cynodon spp.), the most widely used turfgrass on golf courses worldwide. Most bermudagrass cultivars are propagated vegetatively from stolons and rhizomes, and most originate from areas of the United States where Meloidogyne graminis occurs. Therefore, its continued global spread on golf courses beyond the current known range is likely.

\section{Life Cycle and Biology}

As with other nematodes, Meloidogyne graminis has four juvenile stages (J1-J4) and an adult stage. The J1 develops and molts into a J2 inside the egg before hatching (Figures 3 and 4). The J2 is vermiform (worm-shaped), mobile in soil (Figure 5) and within the host plant's roots, and it is the infective stage. The J2 is attracted to a host root and enters into it with its entire body (Figure 6). The J2 nematode migrates within the root to the cortex where it injects parenchyma cells with effectors that cause them to become a feeding site made of multinucleate giant cells. The head of Meloidogyne graminis is usually oriented toward the base of the root and the body is oriented in the opposite direction forming a cane shape (Figure 6). The nematode becomes immobile and remains in that location feeding on the giant cells. The J2 molts into a swollen J3 (Figure 7), then the J3 into an even more swollen J4. Finally, at the final molt the nematode emerges as an adult male or female.

Meloidogyne graminis has sexual dimorphism, meaning the females and males have very dissimilar shapes; the males are vermiform and mobile (Figure 8 ) and the females are swollen and immobile (Figure 9). At the J4 stage, the sex of the developing nematode becomes evident, and the vermiform male body can be seen maturing within the body of the J4 (Figure 10). Most species of root-knot nematode reproduce parthenogenically without mating, and males are rare. However, Meloidogyne graminis reproduces mostly by amphimixis by mating, and males are abundant (Webber and Fox 1971). Male Meloidogyne graminis emerge from the J4 and are mobile, but do not feed as adults. The male exits the root and searches for a female to mate with. Females remain sedentary and continue feeding as they produce eggs. Each female can produce several hundred eggs that are deposited into a gelatinous matrix that protects the eggs as they develop. On some hosts such as bermudagrass and limpograss the female nematode's entire body typically stays embedded within the root, and the eggs are deposited inside as well (Figure 9). On other hosts, like rice and zoysia, the rear end of the mature female breaks the root surface, and eggs are deposited on the root surface (Figure $11)$.

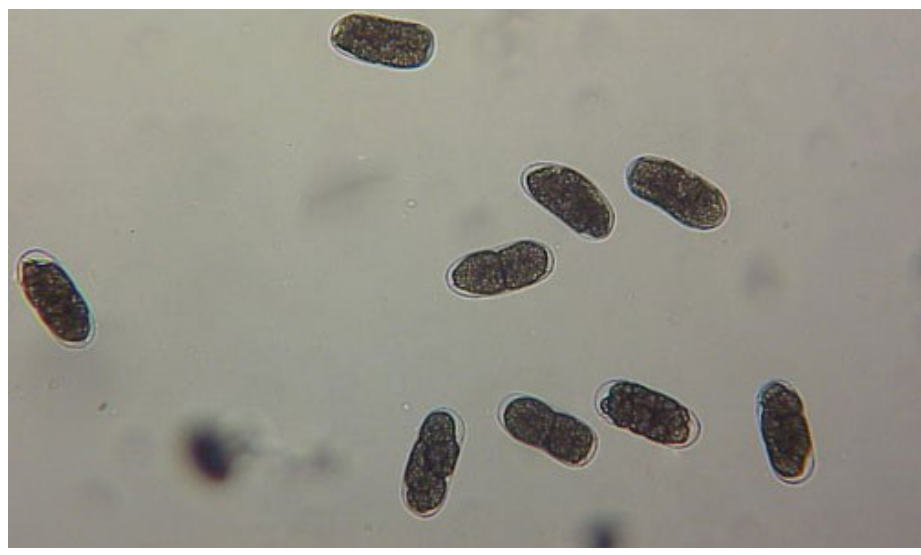

Figure 3. Young eggs of the grass root-knot nematode, Meloidogyne graminis Whitehead Cells are starting to divide. Credits: William T. Crow, UF/IFAS

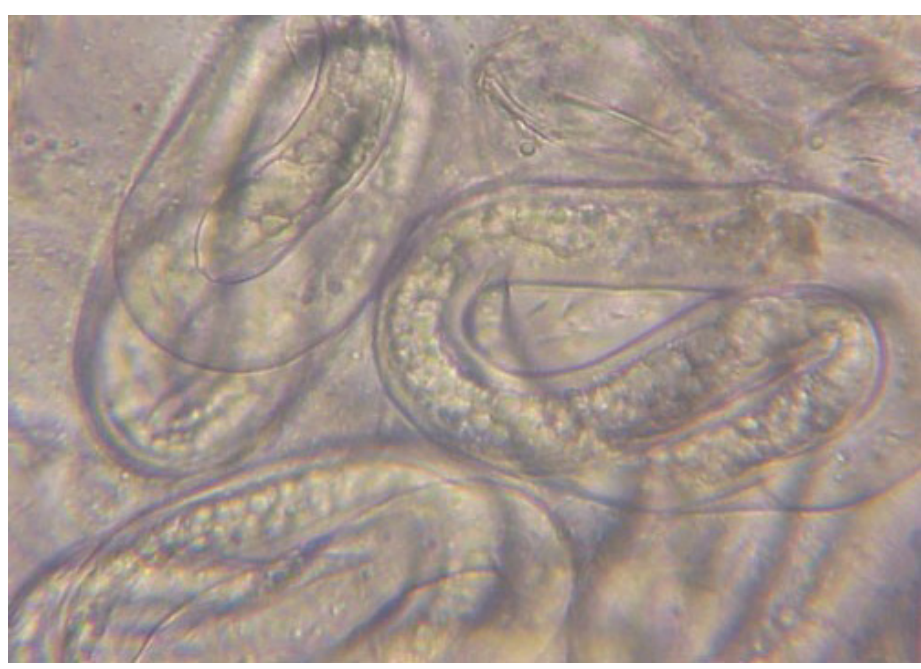

Figure 4. Mature eggs of the grass root-knot nematode, Meloidogyne graminis Whitehead. The second-stage juveniles ( $\mathrm{J} 2$ ) can be seen coiled up inside indicating the egg is getting ready to hatch. Credits: William T. Crow, UF/IFAS 
While Meloidogyne graminis is not as well studied as certain other Meloidogyne spp. like Meloidogyne incognita or Meloidogyne hapla, it is assumed that the plant/nematode interactions for Meloidogyne graminis are similar to those of other Meloidogyne spp. The hollow stylet, or mouth-spear, is used both to inject secretions into plant cells and to withdraw cell contents. Proteins are injected into live root cortical cells that cause them to enlarge into giant cells that form the nematode feeding site. Additional secretions from the nematode cause physiological changes to the plant resulting in carbohydrates moving to the feeding site, where they are then ingested by the nematode. The characteristic galls are caused by proliferation of cells in response to the nematode but are a separate response from the feeding site development.

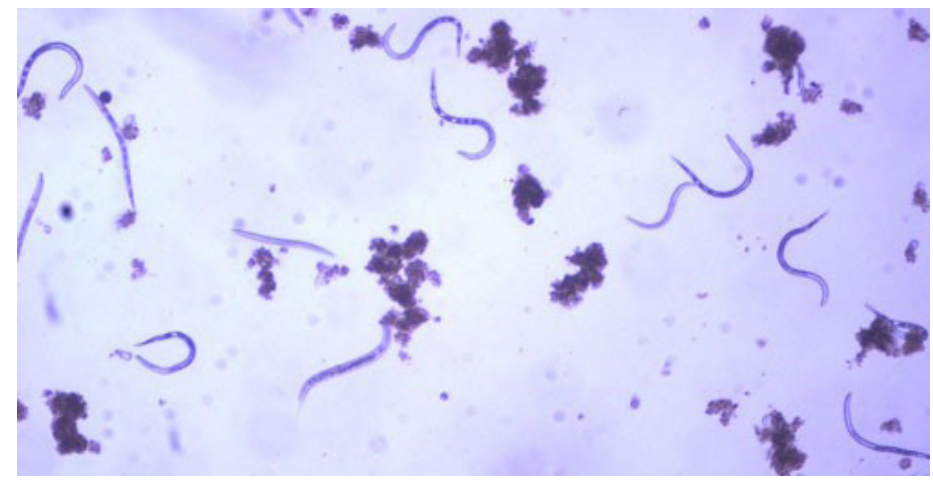

Figure 5. Second-stage juveniles (J2) of the grass root-knot nematode, Meloidogyne graminis Whitehead, extracted from soil, along with a few bacterial-feeding nematodes. $J 2$ are worm-shaped and mobile; this is the infective stage.

Credits: William T. Crow, UF/IFAS

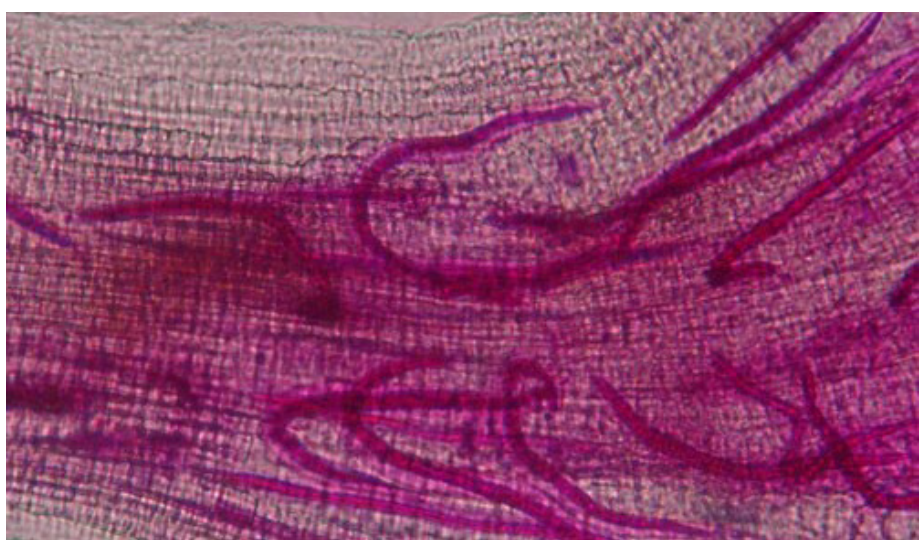

Figure 6. Second-stage juveniles (J2) of the grass root-knot nematode, Meloidogyne graminis Whitehead, inside of a bermudagrass root. Nematodes have been stained red for observation. The J2 have entered the root and are initiating their feeding sites.

Credits: Nick Sikora, UF/IFAS

\section{Symptoms}

Root galls caused by Meloidogyne graminis on grasses are not as large and pronounced as those caused by some other root-knot nematode species on other hosts. Galls tend to be small swellings that can be hard to miss (Figure 12) compared to the large galls caused by certain other root-knot nematodes on other hosts. Egg masses on the root surface are observable on some hosts but not others (Figure 13 a, b). On some hosts like limpograss, the roots crack, and the female nematodes and eggs can be seen within by using a hand lens or dissecting microscope (Figure 14). Meloidogyne graminis tend to congregate within the root with many

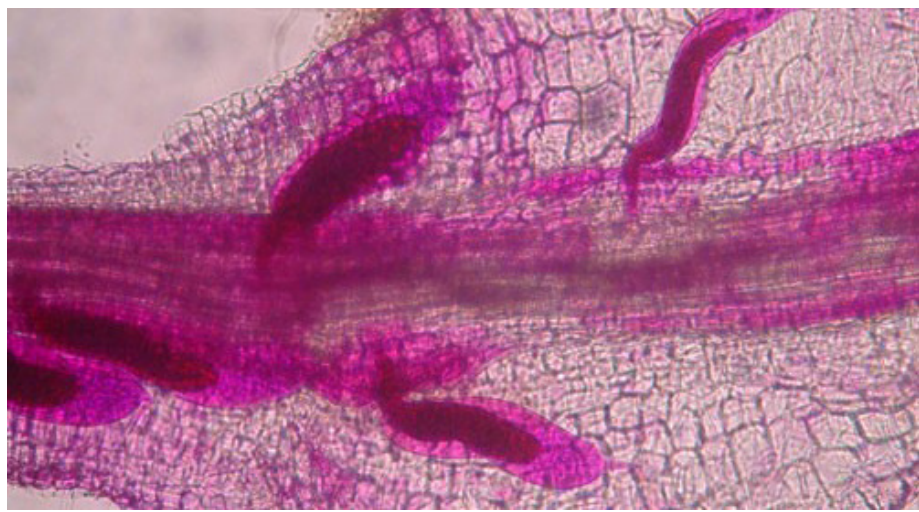

Figure 7. Third-stage juveniles of grass root-knot nematode,

Meloidogyne graminis Whitehead, inside of a bermudagrass root. The nematodes are no longer mobile in this stage. Nematodes have been stained red for observation.

Credits: Nick Sikora, UF/IFAS

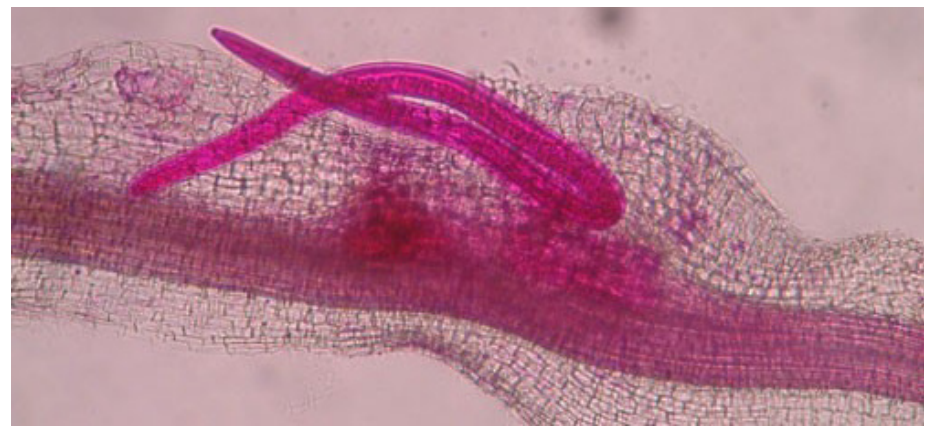

Figure 8. Adult male grass root-knot nematode, Meloidogyne graminis Whitehead, exiting a bermudagrass root. Males are worm-shaped and mobile. The nematode has been stained red for observation. Credits: Nick Sikora, UF/IFAS

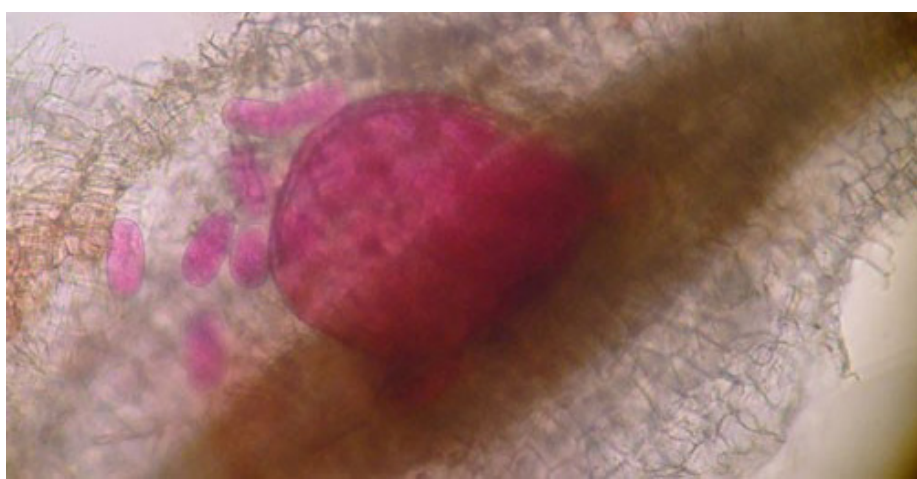

Figure 9. Adult female grass root-knot nematode, Meloidogyne graminis Whitehead, inside of a bermudagrass root. The female is rounded and is starting to lay eggs inside of the root. The nematode has been stained red for observation.

Credits: Nick Sikora, UF/IFAS 


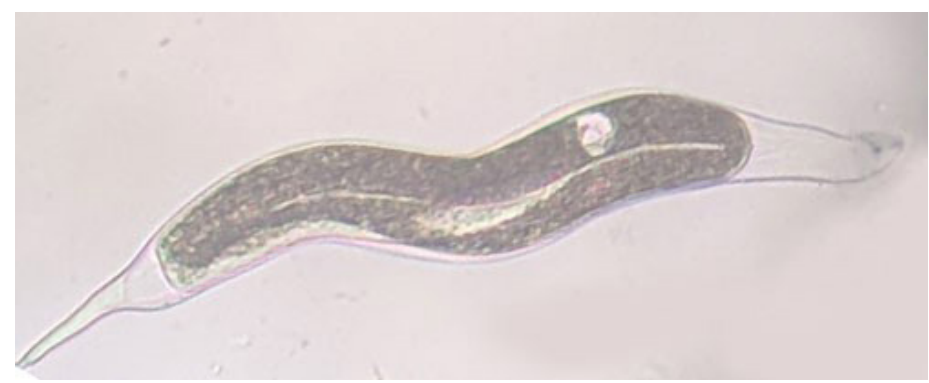

Figure 10. A fourth-stage juvenile (J4) male of the grass root-knot nematode, Meloidogyne graminis Whitehead. The worm-shaped male can be seen developing inside of the J4 body.

Credits: William T. Crow, UF/IFAS

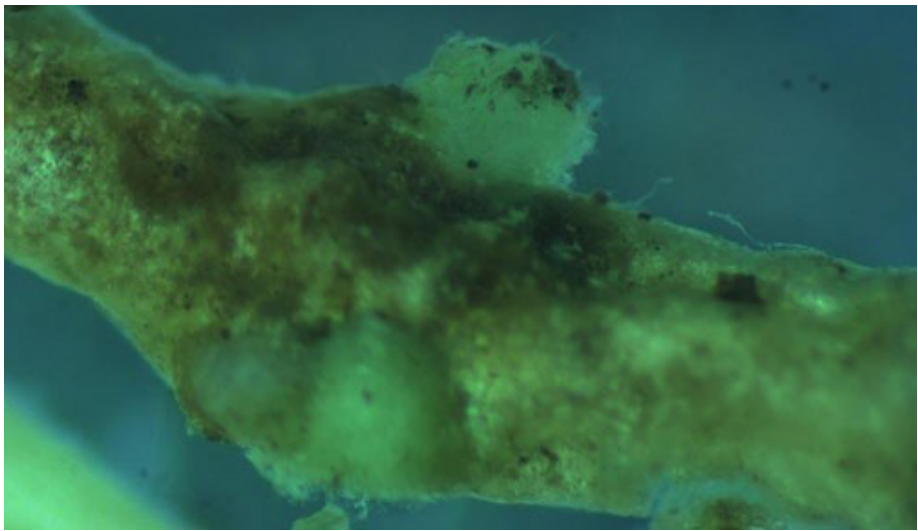

Figure 11. A zoysia root infected by the grass root-knot nematode, Meloidogyne graminis Whitehead. Gelatinous egg masses are present on the surface of the root. On some hosts, like zoysia, most eggs are deposited in egg masses on the root surface.

Credits: William T. Crow, UF/IFAS

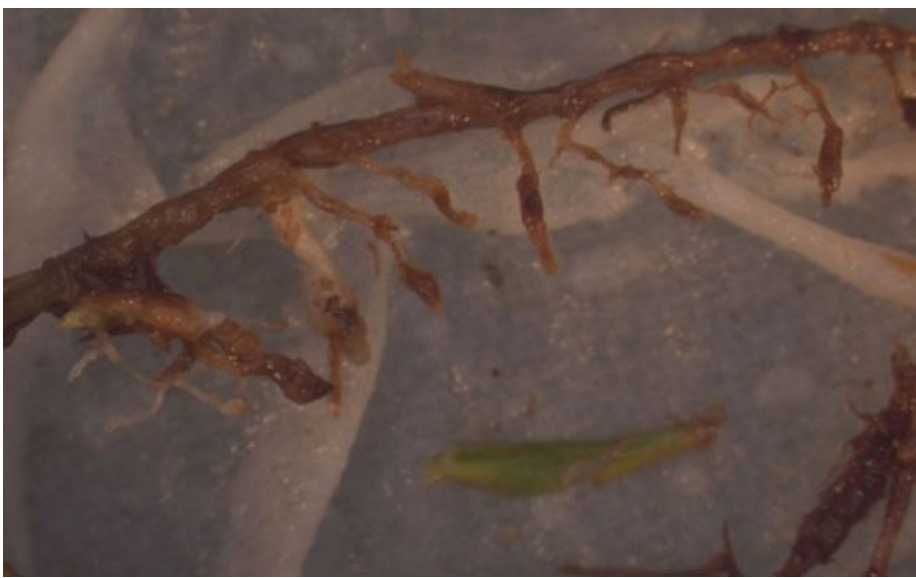

Figure 12. Bermudagrass roots with symptoms of the grass root-knot nematode, Meloidogyne graminis Whitehead. Small galls are present as swellings on the roots, and each gall can contain multiple nematodes. The roots have rotted off below the nematode galls.

Credits: William T. Crow, UF/IFAS

nematodes in close proximity (Figure 5). On golf greens, the roots typically rot off below these infection sites, leading to a shortened root system with very few roots penetrating below the thatch (Figure 15).

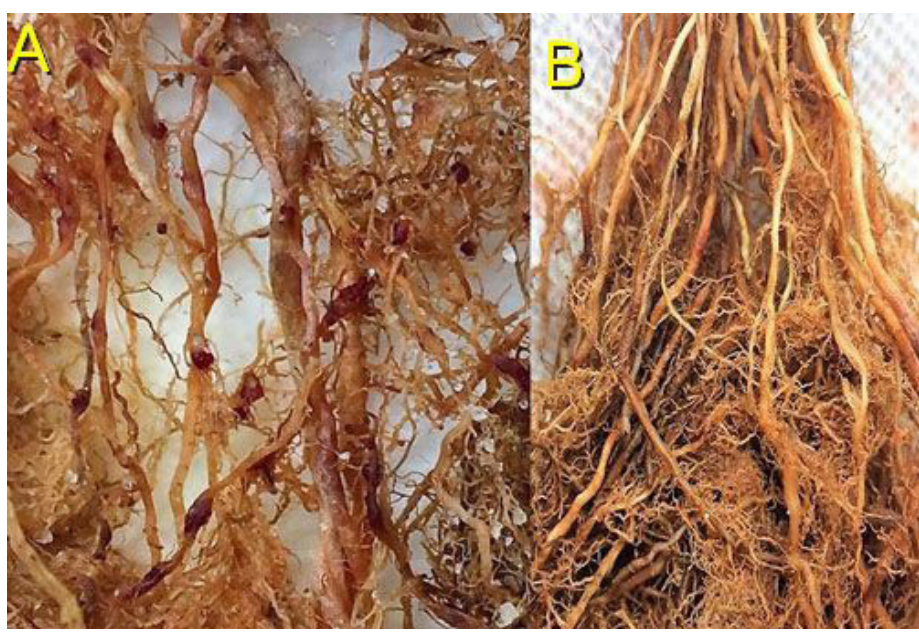

Figure 13. On rice roots (A) female grass root-knot nematode, Meloidogyne graminis Whitehead, can be observed protruding from the roots. The egg masses are on the outside of the roots (nematode egg masses have been stained dark red for observation). On limpograss (B) female Meloidogyne graminis females and egg masses remain inside the roots and are difficult to observe.

Credits: Maria L. Mendes, UF/IFAS

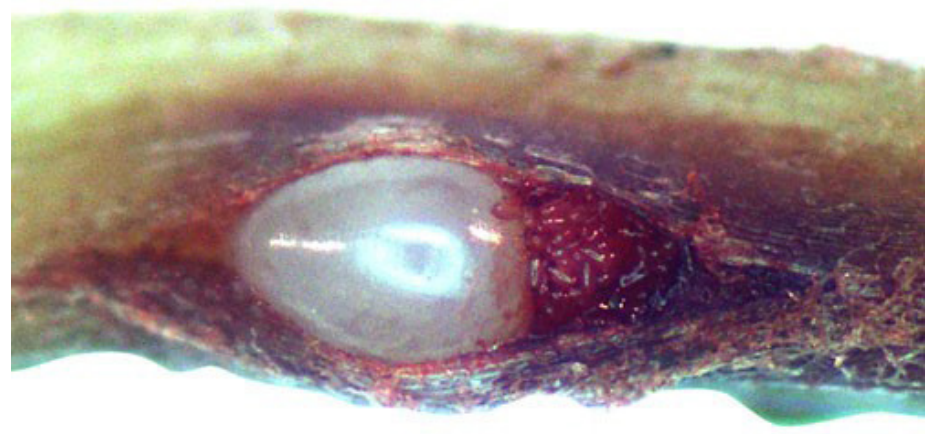

Figure 14. Limpograss root infected by the grass root-knot nematode, Meloidogyne graminis Whitehead. Microscopic observation of a crack in the root reveals a pearly-white female Meloidogyne graminis and her eggs (stained red) inside.

Credits: William T. Crow and Maria L. Mendes, UF/IFAS

Aboveground symptoms include general decline, stunting, and chlorosis (yellowing). Similar to other nematodes, damage often occurs in irregularly shaped patches (Figure 16), but on ultradwarf bermudagrass cultivars used on golf greens, Meloidogyne graminis can also cause chlorotic blotches that have a more circular appearance (Figure 17). Areas with higher numbers of Meloidogyne graminis experience slower plant growth, leading to a bumpy playing surface that interferes with ball rolling.

On turf, Meloidogyne graminis proliferates in the upper soil profile (Laughlin and Williams 1971). Research at the University of Florida has revealed that on golf greens the majority of Meloidogyne graminis infect roots growing in the thatch and upper inch of soil. Further, we have found that the typical nematode soil extraction method used for 
diagnosis of most other turfgrass nematodes often yields inaccurate results for Meloidogyne graminis. Consequently, the University of Florida Nematode Assay Lab recommends using mist extraction of Meloidogyne graminis from turf

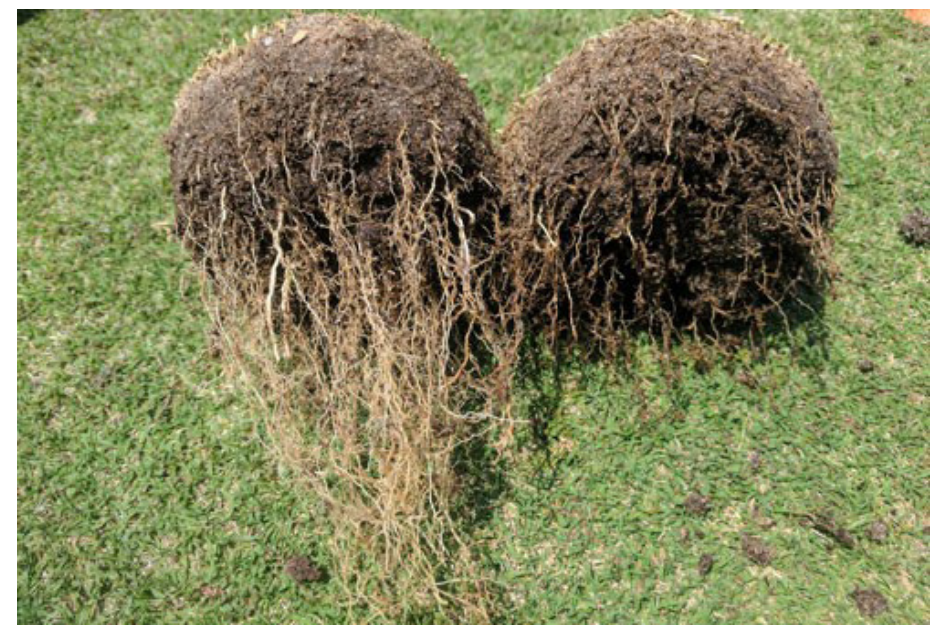

Figure 15. Bermudagrass roots infected by the grass root-knot nematode, Meloidogyne graminis Whitehead. Nematode-damaged roots on right are rotted off below nematode infection sites. Nematicide-treated roots on left are long and healthy. Credits: William T. Crow, UF/IFAS

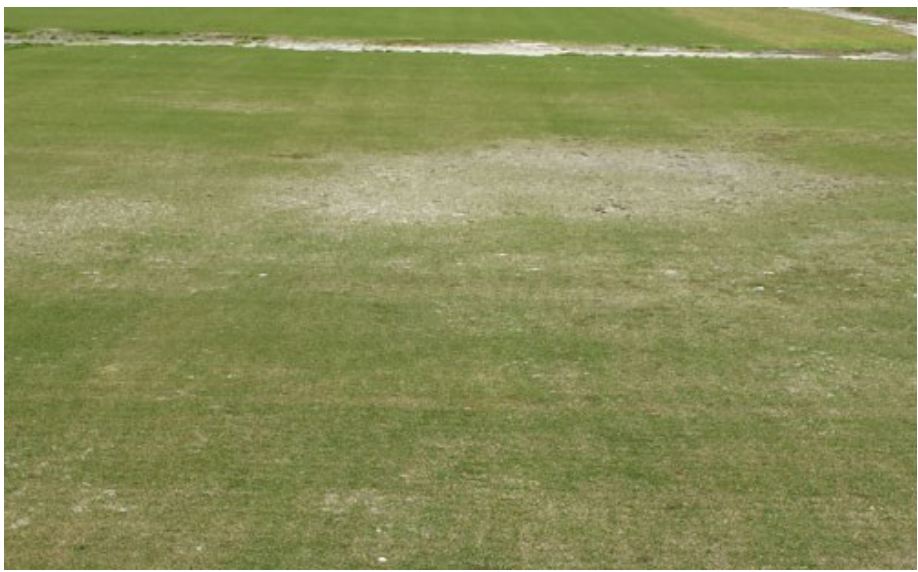

Figure 16. A bermudagrass field infested by the grass root-knot nematode, Meloidogyne graminis Whitehead, showing classic nematode symptoms, irregularly-shaped patches of declining grass. Credits: William T. Crow, UF/IFAS

plugs to collect nematodes for diagnosis. See https://www.

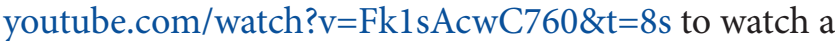
video on how to collect this type of sample. Nematode samples can be submitted to the University of Florida Nematode Assay Lab for diagnosis of Meloidogyne graminis and other nematodes.

While Meloidogyne graminis is the most common species of root-knot nematodes on grasses in Florida, several other species of root-knot nematode have also been reported from grasses in the United States including: Meloidogyne marylandi, Meloidogyne naasi, Meloidogyne minor, Meloidogyne graminicola, and Meloidogyne incognita. The symptoms and behavior of these nematodes on grasses may differ from those reported for Meloidogyne graminis.

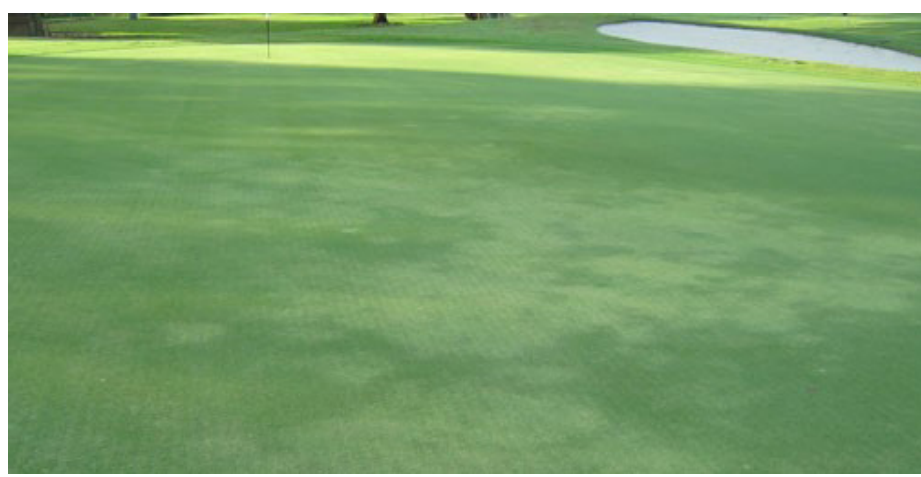

Figure 17. Ultradwarf cultivars of bermudagrasses on golf greens infested by the grass root-knot nematode, Meloidogyne graminis Whitehead, sometimes exhibit chlorotic-rounded blotches. Because these are different from typical nematode symptoms on turf, they often are misdiagnosed in the field.

Credits: William T. Crow, UF/IFAS

Most diagnostic labs identify nematodes only to the genus level. Differentiation among species of Meloidogyne using morphology can be difficult and time consuming. Use of molecular identification methods are both accurate and less tedious than morphological identification, and the costs involved have become reasonable. The University of Florida Nematode Assay Lab can provide this service if needed.

\section{Hosts}

Turfgrass hosts of Meloidogyne graminis include: bermudagrass (Cynodon spp.), St. Augustinegrass (Stenotaphrum secundatum), zoysia (Zoysia spp.), centipede (Eremochloa ophiuroides), seashore paspalum (Paspalum vaginatum), bentgrass (Agrostis spp.), and bluegrass (Poa spp.). Forage and cereal hosts include: forage bermudagrass (Cynodon spp.), limpograss (Hemarthria altissima), Pensacola bahiagrass (Paspalum notatum), fescue (Festuca eliator), rice (Oryza sativa), sorghum (Sorghum bicolor), corn (Zea mays), and wheat (Triticum aestivum). Recent studies at the University of Florida have also shown that the common agricultural weeds yellow nutsedge (Cyperus esculentus) and purple nutsedge (Cyperus rotundus) are both hosts to Meloidogyne graminis.

\section{Management}

To date, there have been no breeding efforts to create grass cultivars that are resistant or tolerant to Meloidogyne graminis. However, evaluation of forage grasses for resistance and tolerance to Meloidogyne graminis are currently underway. Turf and forage grasses are perennial crops, so rotation for 
nematode management is generally not an option on these crops. Nematicides can be effective and economical for management of Meloidogyne graminis on golf courses and some high-end athletic fields but are not economical on forage grasses. Click on these links for current nematode management recommendations for golf courses, lawns, and athletic fields.

\section{Selected References}

Laughlin CW, Williams AS. 1971. "Population behavior of Meloidogyne graminis in field-grown 'Tifgreen' bermudagrass." Journal of Nematology 3: 386-389.

McClure MA, Nischwitz C, Skantar AM, Schmitt ME, Subbotin SA. 2012. "Root-knot nematodes in golf greens of the western United States." Plant Disease 96: 635-647.

Oliveira SA, Oliveira CMG, Maleita CMN, Silva MFA Abrantes IMO, Wilcken SRS. 2018. First report of Meloidogyne graminis on golf courses turfgrass in Brazil. PLoS One 13: e0192397.

Perichi G. 2006. "First report of Meloidogyne graminis (Nematoda: Tylenchida) in Venezuela." Fitopatology Venezuela 19: 17-18.

Sledge EB, Golden AM. 1964. "Hypsoperine graminis (Nematoda: Heteroderidae), a new genus and species of plant-parasitic nematode." Proceedings of the Helminthological Society of Washington 31: 83-88.

Sturhan D. 1976. "Outdoor occurrence of Meloidogyne species in western Germany." Nachrichtenblatt des Deutschen Planzenschultzdienstes 288: 113-117.

Webber AJ, Fox JA. 1971. "Variation in sex differentiation among single larval and single egg mass isolates of Meloidogyne graminis." Journal of Nematology 3: 332-333.

Wesemael W, Viaene N, Moens M. 2011. "Root-knot nematodes (Meloidogyne spp.) in Europe." Nematology 13: $3-16$.

Zeng Y, Ye W, Martin B, Martin M, Tredway L. 2012. "Diversity and occurrence of plant-parasitic nematodes associated with golf course turfgrasses in North and South Carolina, USA." Journal of Nematology 44: 337-347.

Zhuo K, Hu MX, Wang HH, Tang ZL, Shao XY, Liao JL. 2011. "Identification of Meloidogyne graminis on golf greens." Prataculturae Sinica 20: 253-253. 